\title{
The Predictive Ability of Superstitious Thinking in Motivation for Achievement among MA Students at Al-Balqa Applied University
}

\author{
Amaal Al Masri' \\ Moham'd M. Al-Dlalah ${ }^{2}$ \\ Linda Ahmad Khateeb ${ }^{2}$ \\ Asma Naser Alkhawaldeh² \\ ${ }^{1}$ Assistant Professor, Princess Alia University College, \\ Al-Balqa Applied University, \\ Al-Salt, Jordan \\ ${ }^{2}$ Assistant Professor, Faculty of Educational Sciences, \\ Isra University, Al Hezam Road, \\ Amman, Jordan
}

DOI: https://doi.org/10.36941/jesr-2022-0036

Abstract

This study aimed to identify the predictive ability of superstitious thinking in the achievement motivation among master's students in Al Balqa Applied University. To achieve the objectives of the study, two scales were developed: A questionnaire to measure superstitious thinking and a questionnaire to measure achievement motivation after ensuring their validity and reliability. The study sample consisted of (212) males and females. After using arithmetic means, standard deviations, $t$-test, Pearson correlation coefficient, and simple regression analysis, the results of the study found the following: The level of superstitious thinking among master's students in Al Balqa Applied University was low. There are no statistically significant differences in the level of superstitious thinking due to the gender variable. There are no statistically significant differences in the level of superstitious thinking due to the college variable. The level of achievement motivation was high. There are statistically significant differences in the levels of achievement motivation due to the gender variable in favor of females. There are statistically significant differences in achievement motivation among master's students due to the type of college variable in favor of scientific colleges. There is a negative correlation with statistical significance between superstitious thinking and achievement motivation. Superstitious thinking as a whole has a contribution to predicting achievement motivation.

Keywords: Superstitious thinking; Motivation for Achievement; Master's students; Al Balqa Applied University

\section{Introduction}

Thinking is one of the complex mental activities by which God distinguished humans from the rest of his creatures. He endowed him with the gift of reason to use it in the conduct of his life, which is 
reflected positively and leads him to talent, creativity, and excellence; however, some use it in a negative way that hinders and disrupts its growth and progress of the entire society, and superstitious thinking is the most prominent type of thinking that leads to this.

The methods of social upbringing in the family, and the prevailing culture in society, play a significant and essential role in the individual's adoption of specific patterns of thinking, as a large part of the members of our societies are still controlled by the folklore, customs, and traditions more than the scientific laws based on rational explanations. Thus, the mythical superstitious thinking legacy still controls many of our societies, young and old, educated and uneducated, villagers or cities (Abdul Rahim, 2020).

Superstitious thinking is one of the most serious problems facing individuals, which makes their view of the world unrealistic and closer to superstition, and students are affected by these superstitious beliefs in the academic field, such as resorting to the use of amulets, incantations, magic and optimism for a particular day or a particular pen to bring luck and success and to face the challenges that exist at this stage of study (Kamel, 2019).

The achievement motive is one of the essential internal motives in the human motive system, which is affected by way of thinking, and the primary motivator of human behavior to reach a state of equilibrium. The use of the concept of motivation for achievement is due to the scientist Adler, who indicated that achievement motivation is derived from childhood experiences so that the individual makes an effort and continues to try and overcome obstacles to reach success and advanced positions in his life (Al-Masri and Farah, 2020).

Considering that an individual's thinking is one of the primary determinants of his behavior, it is directly reflected in his behavior when his thinking is disturbed. This disorder appears in the individual's self-confidence, self-understanding, and achievement motivation, where scientific thinking and achievement motivation are among the main pillars in achieving the psychological compatibility of the individual and the ability to face difficulties and tireless struggle to achieve success and excellence (Al-Ahmad, 2017). Hence the need to study the predictive ability of superstitious thinking with the motivation for achievement in depth.

The topic of thinking has attracted the attention of researchers in cognitive psychology. It is closely related to the changes of the times that societies are witnessing and the tremendous progress in various fields, primarily technological and scientific ones. It is also considered one of the most important and most prestigious mental processes capable of motivating individuals to face, address and overcome many obstacles to develop human life in various fields and achieve a balanced and integrated life. Thinking is an abstract concept such as justice and generosity because it is an invisible and intangible activity, but we can infer it from its results, and there are different classifications of thinking patterns. Perhaps the most important thing that serves this study is the categories based on objectivity and rationality. It is divided into two parts: non-scientific thinking, which includes superstitious and metaphysical thinking, and scientific thinking, which depends on objectivity and causation and includes reflective, intuitive, deductive, and creative thinking (Jarwan, 2016).

Abu Jadu and Nofal (2017) defined thinking as a symbolic activity and a set of meanings that are raised in the mind when an individual faces a problem, Mustafa (2017) defined it as an active mental process and a kind of continuous internal dialogue with oneself while doing an action or being exposed to a situation, and it may be simple or complex.

Superstitious thinking is considered a bad intellectual habit that an individual acquires through socialization, as superstitious ideas are transmitted from parents to children during the upbringing process that parents practice with their children, making their view of the world unrealistic and closer to superstition. The school and the entire educational system come to complete this process, especially in these difficult circumstances that the world is witnessing in general and the Arab region in particular (Al-Ahmad, 2017). 
Motives are the main engine of human behavior, as no behavior arises without a motive behind it that moves it and directs it towards achieving a biological or psychological balance. Motivation is a theoretical concept with no taste, color, or smell and is not measured directly but inferred from behavior. The motivation for achievement is one of the essential aspects of the human motor system, and it has emerged as one of the distinguishing features of the study and research in the dynamics of personality and behavior. It can even be considered one of the achievements of contemporary human thought (Al-Safi, 2001).

Historically, the use of the term achievement motivation in psychology dates back to Adler, who pointed out that the need for achievement is a compensatory motivation derived from childhood experiences, and Levin, who presented this term in light of his treatment of the concept of ambition, and despite these early beginnings, the first credit goes to the American scientist Murray. In that, he was the first to present the concept of the need for achievement in an accurate way and considered it the individual's keenness to achieve things that others deem difficult and to control the environment, and controlling and organizing ideas, overcoming obstacles, achieving standards of excellence and superiority, competing with others, self-esteem, and the successful exercise of ability (Al-Ahmad, 2017).

The achievement motivation in terms of origin is one of the social motives that the individual acquires from the environment and culture through his life course. Al-baili, Al-Emadi \& Al-Samadi (2020) sees that achievement motivation is a feature that is related to and affected by the family and society, as the family promotes self-initiative, competition, and opportunities to confront and solve problems. Trains the child on independence, would develop and refine the skills related to achievement motivation when parents praise their child in the early years of his life for the successes he achieves and punishes him for the failures, it will stimulate his achievement motivation that appears later in his behavior (Al-Khouli, 2020).

Kamel's (2019) study aimed to identify the level of superstitious thinking and its relationship to the academic self-concept of a sample of secondary school students in the province of Baghdad. The study sample consisted of (513) male and female students, and by using the descriptive-analytical approach, the results of the study revealed that the level of superstitious thinking among secondary school students in the Baghdad governorate was low. It was also found that the level of academic selfconcept among secondary school students in the Baghdad governorate was high, as well as the existence of a significant inverse correlation between superstitious thinking and the students' academic self-concept. While Al-Issa (2019 study aimed to identify the degree of prevalence of superstitious ideas among students of the University of Hail and knowing the impact of the specialization variable on the degree of prevalence of superstitious ideas and to find out whether there is a difference between the level of superstitious thinking and the control center among the students of Hail University. The study sample consisted of (242) female students majoring in nursing, a class teacher, and English language, the results of the study revealed that the level of superstitious thinking among the students was low, and there were statistically significant differences in the impact of specialization on the degree of prevalence of superstitious ideas, in favor of the nursing major. And the percentage of the external control center in the sample was $74.8 \%$. And the internal control center is $\mathbf{2 5 . 2} \%$, and the results revealed significant differences for the control center on the degree of prevalence of superstitious ideas in favor of the external control center. On the other hand, Abdul Rahim (2020) study aimed to identify the attitudes of Saudi female students at the College of Arts at King Saud University towards superstitious thinking and to identify the presence of significant differences in superstitious thinking among female students due to the variables of age, social status, economic level, place of residence, parents' educational level. The study sample consisted of (202) female students and used the descriptive-analytical approach. The study results concluded that the students' attitudes towards superstitious thinking are negative and do not believe in the credibility of superstitious thinking. The study did not reveal significant differences in the students' attitudes 
towards superstitious thinking due to all study variables. Lazem's (2020) study also aimed to know the prevalence of superstitious ideas among female students of the internal departments at the University of Maysan. The study sample consisted of (120) female students from the internal department at the University of Maysan using the descriptive approach. The study results found that the level of superstitious thinking among the students was moderate. Al-Sheikh and Al-Ajil (2019) study examined the achievement motivation of basic stage students in the northern state of Sudan. The study sample consisted of (499) male and female students and used the descriptive approach. The study results revealed that achievement motivation among students was high.Al- Masri and Farah's (2020) study aimed to reveal the level of achievement motivation and its relationship to strategic intelligence among students of King Faisal University in Saudi Arabia and to reveal the impact of the variables (gender and academic level) on both achievement motivation and strategic intelligence. The study sample consisted of (684) male and female students, and the results of the study revealed that the student's level of achievement motivation and strategic intelligence was high. There is a high direct relationship between achievement motivation and strategic intelligence. And there is an effect of gender on achievement motivation in favor of females, and there is an effect of academic level on achievement motivation in favor of the sixth level. The study also revealed no effect of gender and academic level on strategic intelligence. Muhammad and Sharaf (2020) study aimed at identifying the level of achievement motivation among students of the University of Dohuk, and the significance of differences according to the gender variable, as well as the use of an educational program in developing the achievement motivation among students, the experimental study sample consisted of (40) male and female students from the College of Education, Department of Psychology at the University of Dohuk. The results showed that achievement motivation among students was low, and there were no significant differences in achievement motivation due to the student's gender variable. Significant differences appeared for the program's effectiveness and favored the experimental group. Hammoud (2021) study aimed to identify achievement motivation and its relationship to the control center among nursing students at Tishreen University and to identify the differences in achievement motivation and control center according to the variables of gender and academic year; the study sample consisted of (200) male and female students. The results revealed that the students' achievement motivation level was high, and they had an external control center, and there was a significant inverse relationship between achievement motivation and the control center. No significant differences appeared in achievement motivation and control center due to gender and academic year variables. Finally, Simamora's (2021) study aimed at revealing the impact of the expectations of others on the achievement motivation of university students. A sample of business college students from Kwik Kayan University of Business and Technology in Jakarta, Indonesia, was selected, and their number was (203) male and female students from the colleges of business at the university. Two scales were applied to the sample members: the scale of others' expectations and the scale of achievement motivation. The study results revealed that the high expectations of others for the study sample members contribute to their high achievement motivation.

\subsection{The problem of the study and questions}

Suppose the spread of superstitions is harmful to society in general. In that case, their spread among university students, especially graduate students, represents the most significant harm. This is because they are the pillar of the community and the educated elite, as superstitious thinking distances the individual from logical thinking and correct judgments and hinders progress. Moreover, because its spread among this group of students has negative repercussions on the growth of the individual and impedes the growth and prosperity of society, and superstition and science do not meet together, it is a significant obstacle to the motivation for achievement among students, which is the primary driver of human behavior.

In view of the findings of some studies, such as the study of Al-Amir (2018), Kamel (2019), and 
lazem (2020) of the spread of superstitious thinking at different levels among students, and the researchers' observations through their teaching to students, especially in the exceptional circumstances imposed by the Corona pandemic and the transition of learning from face-to-face learning to distance learning, and the various crises that the region is going through, it has made a fertile breeding ground for the spread of superstitious thinking in their ranks at the academic and social levels, in return for an apparent decline in their achievement motivation, and because achievement motivation is one of the essential factors in directing the behavior of individuals and their awareness of situations, and since its presence contributes to the individual's pursuit of selfrealization and planning for the future in order to reach his goals, this study came to try to reveal the predictive ability of superstitious thinking with the achievement motivation among master's students at Al Balqa Applied University in Jordan, by answering the following questions:

1. What is the level of the prevalence of superstitious thinking among master's students in $\mathrm{Al}$ Balqa Applied University?

2. Are there statistically significant differences at the level $(\alpha=0.05)$ in superstitious thinking among master's students in Al Balqa Applied University due to the gender variable?

3. Due to the type of college variable, are there statistically significant differences at the level ( $\alpha$ $=0.05$ ) in the superstitious thinking of master's students in Al Balqa Applied University?

4. What is the level of achievement motivation among master's students in Al Balqa Applied University?

5. Are there statistically significant differences at the level $(\alpha=0.05)$ in the level of achievement motivation among master's students in Al Balqa Applied University due to the gender variable?

6. Are there statistically significant differences at the level $(\alpha=0.05)$ in the level of achievement motivation among master's students in Al Balqa Applied University due to the type of college variable?

7. Is there a statistically significant correlation at the level $(\alpha=0.05)$ between superstitious thinking and achievement motivation among master's students in Al Balqa Applied University?

8. What is the degree of prediction of superstitious thinking among master's students in Al Balqa Applied University of the motivation for achievement?

\subsection{The Objectives of the Study}

1. To identify the level of superstitious thinking among master's students in Al Balqa Applied University.

2. To identify the level of motivation for achievement among master's students in Al Balqa Applied University.

3. To identify the differences in superstitious thinking according to the variables of gender and type of college.

4. To identify the differences in motivation for achievement according to the variables of gender and type of college.

5. To recognize the ability of superstitious thinking in predicting the motivation for achievement.

\subsection{The importance of the study}

The importance of the current study appears in addressing a topic that did not receive much attention from researchers, so this study may be one of the few studies that dealt with these two variables together in an attempt to reveal the predictive ability of superstitious thinking in the achievement motivation among master's students in Al Balqa Applied University.

The importance of the study is shown in the following: 
- First, it dealt with a significant segment of society, namely the postgraduate/master's students' category.

- Enriching theoretical literature and the educational library by providing academic literature on superstitious thinking and motivation for achievement helps researchers and students learn and benefit from this topic.

- Seek to provide literature that helps students move towards scientific thinking based on logic and away from superstitions that rely on hocus pocus.

- Invest the study results in preparing training and counseling programs to raise the students' motivation for achievement.

- Provide a cognitive addition by comparing the current study results with the results of previous studies.

- Researchers benefit from the current study criteria.

- Submit proposals that enrich the research aspect.

\subsection{The limits of the study}

The study was applied within the following limits:

- Objective limits: It detects the predictive ability of superstitious thinking in the motivation for achievement among master's students in Al Balqa Applied University.

- Human limits: The study was applied to a sample of master's students in Al Balqa Applied University.

- Spatial limits: The study was applied at Al Balqa Applied University in Jordan.

- Time limits: The current study was applied in the second semester of the academic year (20202021).

\subsection{The Study Limitations}

The generalization of the results of this study is determined in the light of the following:

- The psychometric characteristics of the study's scales, "The superstitious thinking scale, and the achievement motivation scale," are represented by validity and reliability.

- The integrity of the application procedures and the objectivity of the responses of the study sample to the scales

\section{Definition of Terms}

\section{$2.1 \quad$ Superstitious thinking}

It interprets events and their explanation in ways that are far from science and logic (Al-Qudah, 2013). Foster \& Kokko (2009) defined it as a belief resulting from fear of the unknown, belief in magic, luck, or a false idea of causes. It is defined procedurally as the degree students obtain on the scale of superstitious thinking prepared for this study.

\subsection{Achievement motivation}

\subsubsection{The master's students in Al Balqa Applied University}

Students enrolled in a graduate program (Master's) after completing the bachelor's stage in various Al Balqa Applied University colleges for 2020/2021. 


\section{The Study Methodology}

The descriptive, predictive approach was followed, describing the reality of superstitious thinking and achievement motivation among master's students, then studying the predictive ability of students' superstitious thinking in their achievement motivation.

\subsection{The Study Population}

The study population consisted of all master's students in Al Balqa Applied University from humanitarian and scientific colleges, where the application was applied electronically in the second semester of the academic year. (2020/2021).

\subsection{The Study Sample}

The study sample consisted of (212) male and female students who were randomly selected from master's students in Al Balqa Applied University, representing a percentage of (30\%), and the superstitious thinking scale and the achievement motivation scale were distributed electronically to the students, and Table (1) shows the distribution of the study sample members.

Table 1: Distribution of study sample members of graduate students in Al Balqa Applied University in Jordan, distributed according to gender and college variables

\begin{tabular}{|l|l|c|c|}
\hline Variable & Variable level & Number & Percentage \\
\hline \multirow{4}{*}{ Gender } & Male & 88 & 41.5 \\
\cline { 2 - 4 } & Female & 124 & 58.5 \\
\cline { 2 - 4 } & Total & 212 & 100.0 \\
\hline \multirow{3}{*}{ College } & Humanity & 150 & 70.8 \\
\cline { 2 - 4 } & Scientific & 62 & 29.2 \\
\cline { 2 - 4 } & Total & 212 & 100.0 \\
\hline
\end{tabular}

\subsection{The Study Tools}

Two tools were built to achieve the objectives of the current study, namely: the superstitious thinking scale and the achievement motivation scale, and they are as follows:

\subsubsection{Superstitious thinking scale}

After reviewing the theoretical literature, previous studies, educational research, and standards related to superstitious thinking, such as Al-Amir (2018), Kamel (2019), and Lazem (2020), the researcher built a scale of superstitious thinking, where the scale in its final form included (26) items. As for the indicators of the construct validity of the superstitious thinking, scales were applied to an exploratory sample of graduate students in Al Balqa Applied University in Jordan. Their number was (35) male and female students from the humanitarian scientific disciplines. The sample was from the same population and not from the application sample. Then the correlations of the items measuring superstitious thinking with the total score of the scale were calculated, and the correlation coefficients ranged between ( $0.377-0.665)$, and all correlation coefficients were statistically significant at the significance level (0.05), and Table (2) shows the correlation coefficients of the item with the dimension to which it belongs. 
Table 2: Correlation coefficients between items and the total score of the superstitious thinking scale

\begin{tabular}{|c|c|c|c|c|c|c|c|c|c|c|c|}
\hline Item & Correlation & Sig & Item & Correlation & Sig & Item & Correlation & Sig & Item & Correlation & Sig. \\
\hline 1 & $.403^{*}$ & .016 & 8 & $.610^{* *}$ & .000 & 15 & $.553^{* *}$ & .001 & 22 & $.58^{* *}$ & .001 \\
\hline 2 & $.401^{*}$ & .017 & 9 & $.494^{* *}$ & .003 & 16 & $.603^{* *}$ & .000 & 23 & $.525^{* *}$ & .001 \\
\hline 3 & $.476^{* *}$ & .004 & 10 & $.378^{*}$ & .025 & 17 & $.377^{*}$ & .026 & 24 & $.596^{* *}$ & .000 \\
\hline 4 & $.561^{* *}$ & .000 & 11 & $.634^{* *}$ & .000 & 18 & $.383^{*}$ & .023 & 25 & $.643^{* *}$ & .000 \\
\hline 5 & $.404^{*}$ & .016 & 12 & $.518^{* *}$ & .001 & 19 & $.558^{* *}$ & .001 & 26 & $.626^{* *}$ & .000 \\
\hline 6 & $.46^{* *}$ & .009 & 13 & $.665^{* *}$ & .000 & 20 & $.685^{* *}$ & .000 & & & \\
\hline 7 & $.577^{* *}$ & .000 & 14 & $.523^{* *}$ & .001 & 21 & $.457^{* *}$ & .006 & & & \\
\hline
\end{tabular}

*Significant at the significance level $(\alpha=0.05)$

** Significant at the significance level $(\alpha=0.01)$

\subsubsection{The Reliability of the Superstitious Thinking Scale}

The superstitious thinking Scale was applied to an exploratory sample of graduate students in Al Balqa Applied University in Jordan. Their number was (35) male and female students from the humanities and scientific disciplines, the sample was from the same population and not from the application sample, and the application was repeated again after two weeks. The test/retest reliability was calculated by calculating the Pearson correlation coefficient between the two applications, and the total repetition reliability coefficient was (o.884). The internal consistency reliability was also achieved by calculating the reliability of Cronbach's alpha for the scale of superstitious thinking as a whole on the first application. The overall reliability coefficient was (o.829), and these coefficients are considered high.

\subsubsection{A scale of achievement motivation}

After reviewing the theoretical literature, previous studies, educational research, and the standards used related to achievement motivation, such as Al-Masri and Farah (2020) and Kadi (2016), A scale of achievement motivation was built, where the scale in its final form included (28) items.

The indicators of construction validity for the achievement motivation scale were applied to an exploratory sample of graduate students in Al Balqa Applied University in Jordan. Their number was (35) male and female students from the humanitarian and scientific disciplines. The sample was from the same population and not from the application sample. The correlations of achievement motivation measurement items with the total score of the scale were calculated, and the correlation coefficients ranged between $(0.378-0.758)$, and all correlation coefficients were statistically significant at the significance level (0.05), and Table (3) Shows the correlation coefficients of the items with the dimension to which it belongs.

Table 3: Correlation coefficients between items and the total score of the achievement motivation scale

\begin{tabular}{|c|c|c|c|c|c|c|c|c|c|c|c|}
\hline Item & Correlation & Sig & Item & Correlation & Sig & Item & Correlation & Sig & Item & Correlation & Sig \\
\hline 1 & $.55^{* *}$ & .001 & 8 & $.753^{* *}$ & .000 & 15 & $.428^{*}$ & .010 & 22 & $.583^{* *}$ & .000 \\
\hline 2 & $.56^{* *}$ & .000 & 9 & $.465^{* *}$ & .005 & 16 & $.512^{* *}$ & .002 & 23 & $.428^{*}$ & .010 \\
\hline 3 & $.603^{* *}$ & .000 & 23 & $.664^{* *}$ & .000 & 17 & $.753^{* *}$ & .000 & 24 & $.512^{* *}$ & .002 \\
\hline 4 & $.383^{*}$ & .023 & 11 & $.708^{* *}$ & .000 & 18 & $.465^{* *}$ & .005 & 25 & $.569^{* *}$ & .000 \\
\hline 5 & $.378^{*}$ & .025 & 12 & $.78^{* *}$ & .000 & 19 & $.664^{* *}$ & .000 & 26 & $.626^{* *}$ & .000 \\
\hline 6 & $.653^{* *}$ & .000 & 13 & $.457^{* *}$ & .006 & 20 & $.708^{* *}$ & .000 & 27 & $.657^{* *}$ & .000 \\
\hline 7 & $.584^{* *}$ & .000 & 14 & $.525^{* *}$ & .001 & 21 & $.75^{* *}$ & .000 & 28 & $.641^{* *}$ & .000 \\
\hline
\end{tabular}

${ }^{*}$ Significant at the significance level $(\alpha=0.05)$

** Significant at the significance level $(\alpha=0.01)$ 


\subsubsection{The reliability of the achievement motivation scale}

The superstitious thinking scale was applied to an exploratory sample of graduate students in $\mathrm{Al}$ Balqa Applied University in Jordan, and their number was (35) male and female students from the humanities and scientific disciplines. The sample was from the same population and not from the application sample, and the application was repeated again after two weeks, and the reliability of repetition was calculated by calculating the Pearson correlation coefficient between the two applications, and the total repetition reliability coefficient was (o.863). The internal consistency reliability was also achieved by calculating the reliability of Cronbach's alpha for the scale of superstitious thinking as a whole on the first application. The overall reliability coefficient was (o.812), and these coefficients are considered high.

\subsection{The Study Procedures}

To complete the study, the researcher performed the following procedures:

- First, review the theoretical literature and previous studies related to superstitious thinking and achievement motivation.

- Determine the study population and sample of master's students in Al Balqa Applied University in Jordan.

- Prepare the study tools and ensure their validity and reliability.

- Apply the tools electronically to the study sample.

- Dump the data, process it statistically, and conclude.

- Answer the study questions according to its objectives, discuss them and make recommendations.

\subsection{The Study Variables}

Superstitious thinking and Achievement motivation.

\subsection{Statistical Treatment}

The following was used.

- Arithmetic averages and standard deviations in questions one and four

- T-test to detect statistical differences in the second, third, fifth, and sixth questions

- Pearson's correlation coefficient to answer the seventh question

- Simple regression analysis to answer the eighth question

\section{The Study Results}

The standards were applied to the current study sample of master's students in Al Balqa Applied University, and the appropriate statistical analyzes were carried out, and the results of the study were reached, and they were presented in the order of the questions, which are as follows:

The first question results: What is the prevalence of superstitious thinking among master's students in Al Balqa Applied University?

To answer this question, the arithmetic averages and standard deviations were calculated for the prevalence of superstitious thinking among master's students in Al Balqa Applied University, and Table (4) illustrates this. 
Table 4: Arithmetic averages and standard deviations of the items of the mythical thinking scale among master's students in Al Balqa Applied University, arranged in descending order according to the arithmetic averages

\begin{tabular}{|c|c|c|c|c|c|}
\hline Rank & \begin{tabular}{c|c|c|} 
Item \\
N.
\end{tabular} & Items & $\begin{array}{c}\text { Arithmetic } \\
\text { average }\end{array}$ & $\begin{array}{l}\text { Standard } \\
\text { deviation }\end{array}$ & level \\
\hline 1. & 19 & There are some places where demons live & \begin{tabular}{|l|}
3.42 \\
\end{tabular} & 1.219 & Moderate \\
\hline 2. & 26 & I avoid others a lot for fear of corona infection & 3.15 & 1.311 & Moderate \\
\hline 3. & 22 & I believe that luck works things out for some people & 3.14 & 1.322 & Moderate \\
\hline 4. & 24 & If I dreamed an unpleasant dream, I am upset for this day & 2.73 & 1.291 & Moderate \\
\hline 5. & 1 & After intense laughter, I expect worry and sadness to come & 2.70 & 1.036 & Moderate \\
\hline 6. & 25 & I concealed my success for fear of envy & 2.54 & 1.137 & Moderate \\
\hline 7. & 2 & When I see some people, I feel evil coming & 2.51 & 1.046 & Moderate \\
\hline 8. & 15 & Incense at home from time to time is good for removing envy & 2.42 & 1.420 & Moderate \\
\hline 9. & 12 & Sprinkling salt on the doorstep of the house keeps envy away & 2.35 & 1.387 & Moderate \\
\hline 10. & 18 & Every short person is not without malice & 2.19 & 1.323 & Low \\
\hline 11. & 17 & $\begin{array}{l}\text { The best answer is with the same pen in which you got a } \\
\text { high mark in the previous exam }\end{array}$ & 2.01 & 1.202 & Low \\
\hline 12. & 23 & Knit the left hand as an indication to make money & 2.01 & 1.212 & Low \\
\hline 13. & 4 & Drinking the frightened from the bowl of terror, fear goes away & 2.00 & 1.322 & Low \\
\hline 14. & 10 & A spilled cup of coffee indicates the arrival of good & 1.97 & 1.141 & Low \\
\hline 15. & 16 & I am pessimistic and optimistic about certain days and certain numbers & 1.92 & 1.174 & Low \\
\hline 16. & 11 & \begin{tabular}{|l|l} 
Seeing a black cat at night portends bad luck \\
\end{tabular} & 1.80 & 1.176 & Low \\
\hline 17. & 9 & I believe in the magic that leads to divorce & 1.79 & 1.113 & Low \\
\hline 18. & 5 & I think that an inverted shoe in the house brings evil & 1.77 & 1.316 & Low \\
\hline 19. & 3 & $\begin{array}{l}\text { It affects the reading of my horoscope in the morning, } \\
\text { whether with happiness or distress }\end{array}$ & 1.66 & 1.164 & Low \\
\hline 20. & 13 & The suspension of the blue eye in the car works to keep envy away. & 1.54 & .999 & Low \\
\hline 21. & 6 & I trust reading the cup & 1.35 & .768 & Low \\
\hline 22. & 14 & Palm reading predicts the future of the individual in most cases. & 1.34 & .708 & Low \\
\hline 23. & 20 & There is an hour to jinx on Friday & 1.25 & .701 & Low \\
\hline 24. & 8 & Turn to the elders and fortune-tellers for whatever reason. & 1.23 & .597 & Low \\
\hline 25. & 7 & I believe magic protects one from harm & 1.22 & .595 & Low \\
\hline 26. & 21 & Putting a horseshoe on the door of the house prevents evil. & 1.14 & .495 & Low \\
\hline \multicolumn{3}{|c|}{ The total degree of superstitious thinking } & 2.04 & .536 & Low \\
\hline
\end{tabular}

Table (4) shows that the level of the prevalence of superstitious thinking among master's students in Al Balqa Applied University was low, as the arithmetic average of the total degree was (2.04) with a standard deviation of (0.536). The arithmetic averages of the items ranged between $(1.14-3.42)$. The levels of the things ranged between low and moderate, and item (19), which states: " There are some places where demons live," came in the first rank with the highest arithmetic average of (3.42) with a standard deviation (219.1) and a level of moderate rating, while item (21) which states: "Putting a horseshoe on the door of the house prevents evil" came in the last rank, with an arithmetic average of (1.14) with a standard deviation of (495.) and at a low estimate level.

The results of the second question: Are there statistically significant differences at the level $(\alpha=0.05)$ in the level of superstitious thinking among master's students in Al Balqa Applied University due to the gender variable?

Arithmetic averages, standard deviations, and t-test were extracted to detect statistical differences in superstitious thinking among master's students in Al Balqa Applied University according to the gender variable, and Table (5) illustrates this. 
Table 5: Arithmetic averages, standard deviations, and t-test to detect statistical differences in superstitious thinking among master's students in Al Balqa Applied University by gender variable

\begin{tabular}{|l|l|c|c|c|c|c|c|}
\hline Scale & Gender & $\mathbf{N}$. & $\begin{array}{c}\text { Arithmetic } \\
\text { average }\end{array}$ & $\begin{array}{c}\text { Standard } \\
\text { deviation }\end{array}$ & $\begin{array}{c}\mathbf{T} \\
\text { value }\end{array}$ & df & $\begin{array}{c}\text { Statistical } \\
\text { significance }\end{array}$ \\
\hline $\begin{array}{l}\text { Superstitious } \\
\text { thinking }\end{array}$ & Male & 88 & 2.05 & .609 & .217 & 210 & .829 \\
\cline { 2 - 8 } & Female & 124 & 2.04 & .481 & .217 & .829 \\
\hline
\end{tabular}

Table (5) shows that there are no statistically significant differences $(a=0.05)$ in the levels of superstitious thinking according to the gender variable, where the statistical significance was (o.829), and this significance is higher than (0.05), which indicates that there are no statistical differences in superstitious thinking attributed to the gender variable. The researcher attributes this result to the characteristics of the study sample, who are master's students, and their awareness and cognitive, psychological, and social maturity, regardless of gender, which made them reject such superstitious ideas, discuss controversial issues and reject any thinking that is not based on a logical basis. This result agreed with the study of Hussain (2018) and Abdul Rahim (2020).

The results of the third question: Are there statistically significant differences at the level ( $\alpha$ $=0.05$ ) in the superstitious thinking of master's students in Al Balqa Applied University due to the type of college variable?

Arithmetic means, standard deviations, and t-test was extracted to detect statistical differences in superstitious thinking among master's students in Al Balqa Applied University according to the college variable, and Table (6) illustrates this.

Table 6: Arithmetic averages, standard deviations, and t-test to detect statistical differences in superstitious thinking among master's students in Al Balqa Applied University according to the college variable

\begin{tabular}{|l|l|l|c|c|c|c|c|}
\hline Scale & College & N. & $\begin{array}{c}\text { Arithmetic } \\
\text { average }\end{array}$ & $\begin{array}{c}\text { Standard } \\
\text { deviation }\end{array}$ & $\begin{array}{c}\text { T } \\
\text { value }\end{array}$ & df & $\begin{array}{c}\text { Statistical } \\
\text { significance }\end{array}$ \\
\hline $\begin{array}{l}\text { Superstitious } \\
\text { thinking }\end{array}$ & Humanity & 150 & 2.05 & .561 & .263 & 210 & .793 \\
\cline { 2 - 5 } & Scientific & 62 & 2.03 & .475 & .263 & .793 \\
\hline
\end{tabular}

Table (6) shows that there are no statistically significant differences $(a=0.05)$ in the levels of superstitious thinking according to the college variable, where the statistical significance was (o.793). This significance is higher than (0.05), indicating no statistical differences in superstitious thinking attributed to the college variable.

Results of the fourth question: What is the level of achievement motivation among master's students in Al Balqa Applied University?

To answer this question, the arithmetic averages and standard deviations of the achievement motivation level among master's students in Al Balqa Applied University were calculated, and Table (7) illustrates this.

Table 7: Arithmetic averages and standard deviations of the items of the achievement motivation scale among master's students in Al Balqa Applied University, arranged in descending order according to the arithmetic averages

\begin{tabular}{|c|c|c|c|c|c|}
\hline Rank & \begin{tabular}{|c|} 
Item \\
$\mathrm{N}$.
\end{tabular} & Items & $\begin{array}{c}\text { Arithmetic } \\
\text { average }\end{array}$ & $\begin{array}{l}\text { Standard } \\
\text { deviation }\end{array}$ & level \\
\hline 1. & 1 & Do what I can to secure my future. & 4.57 & .767 & High \\
\hline 2. & 27 & When I commit to something, I stick to it no matter the circumstances. & $4 \cdot 55$ & .704 & High \\
\hline 3. & 12 & I get annoyed if I do something and don't finish it to the fullest. & 4.45 & .804 & High \\
\hline 4. & 22 & I rely on myself to do my homework & 4.44 & .888 & High \\
\hline
\end{tabular}




\begin{tabular}{|c|c|c|c|c|c|}
\hline Rank & \begin{tabular}{|c|} 
Item \\
N.
\end{tabular} & Items & $\begin{array}{c}\text { Arithmetic } \\
\text { average }\end{array}$ & $\begin{array}{l}\text { Standard } \\
\text { deviation }\end{array}$ & level \\
\hline 5. & 19 & I don't want the major I'm studying & \begin{tabular}{|l|}
4.43 \\
\end{tabular} & \begin{tabular}{|l|l}
1.080 \\
\end{tabular} & High \\
\hline 6. & 7 & I think about my future more than in the past & 4.41 & .764 & High \\
\hline 7. & 5 & I need to get the highest grades & 4.40 & .995 & High \\
\hline 8. & 10 & I always try to see what's new. & 4.38 & .826 & High \\
\hline 9. & 24 & I think a lot about quitting studies & 4.25 & 1.272 & High \\
\hline 10. & 18 & I feel upset if I'm late for class & 4.20 & 1.048 & High \\
\hline 11. & 11 & Keeping appointments is sacred to me & 4.17 & 1.008 & High \\
\hline 12. & 4 & I love the business that is challenging. & 4.13 & .965 & High \\
\hline 13. & 25 & I consider myself a lively and energetic person & 4.13 & .875 & High \\
\hline 14. & 26 & I feel bad for indifferent people & 4.13 & 1.001 & High \\
\hline 15. & 2 & I get angry if I don't get a high score on the test & 4.11 & 1.024 & High \\
\hline 16. & 8 & I enjoy tasks that require a lot of thought and research. & 4.08 & .897 & High \\
\hline 17. & 3 & I work hard to outperform my colleagues & 3.97 & 1.331 & High \\
\hline 18. & 6 & I decide what I want to do within a timetable & 3.90 & 1.131 & High \\
\hline 19. & 14 & I feel that continuing to solve a complex problem is a waste of time & 3.67 & 1.222 & Moderate \\
\hline 20. & 16 & Performing duties and chores is a burden for me & 3.53 & 1.166 & Moderate \\
\hline 21. & 20 & $\begin{array}{l}\text { I only study to get a high degree that will benefit me } \\
\text { financially and in the way others see me }\end{array}$ & $3 \cdot 52$ & 1.535 & Moderate \\
\hline 22. & 13 & I think of the moment I live in, and I believe no further & 3.19 & 1.213 & Moderate \\
\hline 23. & 9 & When I fail at a job, I leave it and go for something else & 3.18 & 1.180 & Moderate \\
\hline 24. & 28 & $\begin{array}{l}\text { The conditions that the region is going through weaken my } \\
\text { motivation for any work }\end{array}$ & 3.09 & 1.277 & Moderate \\
\hline 25. & 23 & I choose my friends from the hardworking students & 3.05 & 1.177 & Moderate \\
\hline 26. & 15 & I am the best business that requires much effort & 3.02 & 1.210 & Moderate \\
\hline 27. & 21 & I postpone my studies until shortly before the exam & 2.82 & 1.273 & Moderate \\
\hline 28. & 17 & I just studied the syllabus for the exam & 2.32 & 1.127 & Low \\
\hline \multicolumn{3}{|c|}{ The overall score for achievement motivation } & 3.86 & .434 & High \\
\hline
\end{tabular}

Table (7) shows that the level of achievement motivation among master's students in Al Balqa Applied University was high, as the arithmetic means of the total degree was (3.86) with a standard deviation of (0.434). The arithmetic averages of the items ranged between $(2.32-4.57)$. The levels of the items ranged between low, moderate, and high, and item (1), which states: "I do what I can to secure my future," came in the first rank with the highest arithmetic average of (4.57) with a standard deviation of (767.0) with a high level of appreciation, while item (17), which states: "I just study the syllabus for the exam," came in the last rank, with an arithmetic average of (2.32) with a standard deviation of (127.1) and a low rating level.

The results of the fifth question: Are there statistically significant differences at the level $(\alpha=$ 0.05) in the level of achievement motivation among master's students in Al Balqa Applied University due to the gender variable?

Arithmetic averages, standard deviations, and t-test were extracted to detect statistical differences in superstitious thinking among master's students in Al Balqa Applied University according to the gender variable, and Table (8) illustrates this.

Table 8: Arithmetic averages, standard deviations, and t-test to detect statistical differences in superstitious thinking among master's students in Al Balqa Applied University by gender variable

\begin{tabular}{|l|l|l|c|c|c|c|c|}
\hline Scale & Gender & N. & $\begin{array}{c}\text { Arithmetic } \\
\text { average }\end{array}$ & $\begin{array}{c}\text { Standard } \\
\text { deviation }\end{array}$ & $\begin{array}{c}\text { T } \\
\text { value }\end{array}$ & df & Sig. \\
\hline $\begin{array}{l}\text { Achievement } \\
\text { motivation }\end{array}$ & Male & 88 & 3.76 & .399 & -3.019 & 210 & .003 \\
\cline { 2 - 8 } & Female & 124 & 3.93 & .443 & -3.93 & \\
\hline
\end{tabular}

Table (8) shows that there are statistically significant differences $(\mathrm{a}=0.05)$ in the levels of 
achievement motivation according to the gender variable, where the statistical significance was (o.003). However, this significance is less than (0.05), which indicates that there are statistical differences in the achievement motivation due to the gender variable, the differences were in favor of females, whose arithmetic average was (3.93), which is higher than the arithmetic average for females, which reached (3.76).

Results of the sixth question: Are there statistically significant differences at the level $(\alpha=$ 0.05) in the achievement motivation of master's students in Al Balqa Applied University due to the type of college variable?

Arithmetic averages, standard deviations, and t-test were extracted to detect statistical differences in achievement motivation among master's students in Al Balqa Applied University according to the college variable, and Table (9) illustrates this.

Table 9: Arithmetic averages, standard deviations, and t-test to detect statistical differences in achievement motivation among master's students in Al Balqa Applied University according to the type of college variable

\begin{tabular}{|l|l|c|c|c|c|c|c|}
\hline Scale & College & N. & $\begin{array}{c}\text { Arithmetic } \\
\text { average }\end{array}$ & $\begin{array}{c}\text { Standard } \\
\text { deviation }\end{array}$ & $\begin{array}{c}\text { T } \\
\text { value }\end{array}$ & df & Sig. \\
\hline $\begin{array}{l}\text { Achievement } \\
\text { motivation }\end{array}$ & Humanity & 150 & 3.80 & .411 & -2.964 & 210 & .003 \\
\cline { 2 - 8 } & Scientific & 62 & 3.99 & .461 & -964 & 203 & \\
\hline
\end{tabular}

Table (9) shows that there are statistically significant differences $(a=0.05)$ in the levels of achievement motivation according to the variable of the type of college, where the statistical significance was (0.003). This significance is less than (0.05), which indicates statistical differences in the achievement motivation due to the college variable. The differences favored the scientific faculties, whose arithmetic average was (3.99), which is higher than the arithmetic average of the humanities faculties, which reached (3.80).

The results of the seventh question: Is there a statistically significant correlation at the level $(\alpha=0.05)$ between superstitious thinking and achievement motivation among master's students in $\mathrm{Al}$ Balqa Applied University?

To answer this question, Pearson's correlation coefficient was calculated to reveal the correlation between superstitious thinking and achievement motivation among master's students in Al Balqa Applied University, and Table (10) shows the correlation coefficients, which are as follows:

Table 10: Results of Pearson's correlation coefficient between superstitious thinking and achievement motivation among master's students in Al Balqa Applied University

\begin{tabular}{|l|l|c|}
\hline Variable & Correlation & Achievement motivation \\
\hline Superstitious thinking & Pearson's correlation coefficient & $-.323^{* *}$ \\
\cline { 2 - 3 } & Statistical significance & .000 \\
\cline { 2 - 3 } & Sample number & 212 \\
\hline
\end{tabular}

The results of Table (10) revealed the existence of a negative correlation with statistical significance between superstitious thinking and achievement motivation among master's students in Al Balqa Applied University, where the Pearson correlation coefficients between the two variables were $\left({ }^{* *}\right.$ $0.323)$, which is a statistical function at the significance level $(\alpha=0.05)$, where the value of the statistical significance was (o.ooo).

The results of the eighth question: What is the degree of prediction of superstitious thinking among master's students in Al Balqa Applied University with the achievement motivation?

To answer this question and determine the extent of the contribution of superstitious thinking among master's students in Al Balqa Applied University in predicting their achievement motivation, a 
simple regression analysis was used according to the total method (Enter), and Table (11) illustrates this:

Table 11: The results of simple regression analysis to determine the extent of the contribution of superstitious thinking among master's students in Al Balqa Applied University in predicting their achievement motivation

\begin{tabular}{|l|l|c|c|c|c|c|c|c|}
\hline $\begin{array}{l}\text { Dependent } \\
\text { variable }\end{array}$ & $\begin{array}{l}\text { Interpreted } \\
\text { predictive } \\
\text { variables }\end{array}$ & $\begin{array}{c}\text { Correlation } \\
\mathbf{R}\end{array}$ & $\begin{array}{c}\text { R2. coefficient of } \\
\text { determination }\end{array}$ & $\begin{array}{c}\mathbf{F} \\
\text { value }\end{array}$ & $\begin{array}{c}\text { F Statistical } \\
\text { significance }\end{array}$ & $\begin{array}{c}\text { Beta } \\
\text { value }\end{array}$ & $\begin{array}{c}\mathbf{T} \\
\text { value }\end{array}$ & $\begin{array}{c}\mathbf{T} \\
\text { Sig. }\end{array}$ \\
\hline $\begin{array}{l}\text { Achievement } \\
\text { motivation }\end{array}$ & $\begin{array}{l}\text { Superstitious } \\
\text { thinking }\end{array}$ & .323 & .105 & 24.508 & .000 & -.323 & 11.436 & .000 \\
\hline
\end{tabular}

- (independent variable): Superstitious thinking.

- (dependent variable): achievement motivation

The results show that superstitious thinking as a whole has a contribution to the interpretation, variance, or prediction of achievement motivation, where the value of $(t)$ was (11.436), and with statistical significance (o.0oo), and the value of Beta was (0.323), which explained the total score Superstitious thinking accounted for (10.5\%) in the change in achievement motivation among master's students in Al Balqa Applied University.

\section{Discussion of the Results}

The first question results: What is the level of the prevalence of superstitious thinking among master's students in Al Balqa Applied University?

The researcher attributes this result to the intellectual maturity of the master's students, in addition to the cognitive characteristics of master's students that distinguish them from other students, as they possess the skills and abilities that qualify them to exclude superstitious ideas and beliefs that contradict scientific and logical thinking, in addition to adhering to religious education that rejects such ideas, as well as the tremendous technological development that made it easier for the student to access information from its original source. This result agreed with the study of Kamel (2019) and Al-Issa (2019), and it differed from the study of Lazem (2020), whose results concluded that the students' superstitious thinking was moderate.

The results of the second question: Are there statistically significant differences at the level $(\alpha=0.05)$ in the level of superstitious thinking among master's students in Al Balqa Applied University due to the gender variable?

The researcher attributes this result to the characteristics of the study sample, who are master's students, and their awareness and cognitive, psychological, and social maturity, regardless of gender, which made them reject such superstitious ideas, discuss controversial issues and reject any thinking that is not based on a logical basis. This result agreed with the study of Hussain (2018) and Abdul Rahim (2020).

The results of the third question: Are there statistically significant differences at the level $(\alpha=0.05)$ in the superstitious thinking of master's students in Al Balqa Applied University due to the type of college variable?

The researcher attributes this result to the fact that higher university education reduces the importance of ideas that contradict logic and does not encourage unscientific thinking, and that the general culture prevailing among master's students is almost the same, in addition to the cognitive maturity of graduate students as a result of what they watch, read and research, regardless of the type of college. This result agreed with the study of Abdul Rahim (2020). However, it differed from the study of Al-Issa (2019), whose results revealed the existence of statistically significant differences in the superstitious thinking of students due to the type of college (specialization) in favor of scientific 
disciplines.

Results of the fourth question: What is the level of achievement motivation among master's students in Al Balqa Applied University?

The researcher attributes this result to the fact that the postgraduate / master's studies stage is not like the bachelor's stage, where the student enrolls in it with self-motivation voluntarily, as success in it represents a worthwhile goal for the student through which he satisfies his ambitions and goals. Students of this stage of university education realize that seriously accomplishing the tasks entrusted to them is the way to achieve these ambitions and goals, which increases their achievement motivation, and this result agreed with the study of Al-Sheikh and Al-Ajil (2019), Al-Masri and Farah (2020) and Hammoud (2021). However, it differed from the study of Muhammad and Sharaf (2020), which revealed that the study's results showed low achievement motivation among students.

The results of the fifth question: Are there statistically significant differences at the level $(\alpha=0.05)$ in the level of achievement motivation among master's students in Al Balqa Applied University due to the gender variable?

The researcher attributes this result to the nature of the Jordanian society, of which the study sample is a part, as it is a male-dominated society, which pushes females to the challenge by making a more significant effort to prove themselves to draw attention to their superiority and achievements. Also, females staying at home for a more extended period than males allow them to complete the tasks entrusted to them; in addition. The student's access to the postgraduate stage will not occur without the student-facing great challenges that outweigh the challenges faced by the student, which makes her feel that the success she has achieved is mainly the result of achievement motivation. This result agreed with the study of Al-Masri and Farah (2020). However, it differed from the study of AlAhmad (2017), Muhammad and Sharaf (2020), and Hammoud (2017), whose results revealed that there were no significant differences in students' achievement motivation due to gender variables.

Results of the sixth question: Are there statistically significant differences at the level $(\alpha$ $=0.05)$ in the achievement motivation of master's students in Al Balqa Applied University due to the type of college variable?

The researcher attributes this result to the societal view of science majors as more complex and essential than humanities since students chose to major in secondary school (scientific/literary). Therefore, the scientific specialization needs to make more effort to achieve high levels of success, which was reflected in the motivation for achievement among master's students in scientific disciplines, which prompted them to make a more significant effort.

The results of the seventh question: Is there a statistically significant correlation at the level $(\alpha=0.05)$ between superstitious thinking and achievement motivation among master's students in Al Balqa Applied University?

The researcher explains this result because students who have a high level of superstitious thinking have a negative concept of themselves and low confidence in themselves and their abilities, which negatively affects the completion of the tasks assigned to them on time. They are afraid to face obstacles and difficulties. They are so scared of challenge and competition, as this reflects negatively on the motivation for achievement, unlike students with a high motivation for achievement who are willing to take responsibility and overcome difficulties and can think scientifically and logically and search for evidence to prove or deny the idea and have creativity and search for new. This result agreed with the study of Al-Ahmad (2017).

The results of the eighth question: What is the degree of prediction of superstitious thinking among master's students in Al Balqa Applied University with the achievement motivation?

This result indicates that superstitious thinking contributes by (10.5\%) to the achievement motivation of master's students, which means that this percentage contributes to the formation of low or high achievement motivation, in addition to the other factors that contribute to the largest percentage, which is $(89.5 \%)$. These factors may be personal, academic, social, family, and other factors, and in summary, it appears that students' superstitious thinking affects their achievement motivation. 


\section{Recommendations}

In light of the study results

- Provide training programs that will raise achievement motivation among male master's students and students of humanities colleges.

- Conduct further studies on the phenomenon of superstitious thinking and its relationship to other variables such as self-concept and psychological compatibility.

- Prepare programs to train students on scientific and logical thinking and reduce superstitious thinking.

\section{References}

Abdul Rahim, A. (2020). Superstitious thinking between belief and scientific realism, Journal of Social Affairs, Sharjah, 37(146), 33-84.

Abu Jadu, S.\& and Nofal, M. (2017). Teaching Thinking: Theory and Application, 6th Edition, Dar Al Masirah for Publishing and Distribution, Amman: Jordan.

Al-sheik, F. \& Al-Ajil, A. (2019). Achievement Motivation among Basic Stage Students in the Northern State in Sudan, Jill Journal of Humanities and Social Sciences, Algeria, 55(1), 25-39

Al-Ahmad, A. (2017). The relationship between achievement motivation and superstitious thinking among a sample of education students at the University of Damascus, Journal of the Association of Arab Universities for Education and Psychology, Damascus, 15(2), 14-53. http://search.shamaa.org/PDF/Articles/SYAaujep /AaujepVol15No2Y2017/aaujep_2017-v15-n2_014-053.pdf

Al-Amir, A. (2018). Superstitious Thinking among Students of the College of Education, research to obtain a bachelor's degree, University of Al-Qadisiyah, Iraq.

Al-Baili, M., Al-Emadi, A. \& Al-Samadi, A. (2020). Educational psychology and its applications, 6th edition. AlFalah Library for Publishing and Distribution, Jordan.

Al-Issa, H. (2019). Superstitious thinking and its impact on the control center of Hail University students, International Specialized Educational Journal, Jordan, 8(1), 18-26.

Al-Khouli, H. (2020). Cognitive methods and their controls in psychology, modern Book House, Cairo.

Al-Masri, T. \& Farah, A. (2020). Achievement motivation and its relationship to strategic intelligence among students of King Faisal University in the Kingdom of Saudi Arabia, Journal of the Islamic University of Educational and Psychological Studies, Gaza, Palestine, 28(3), 26o-289. http://dx.doi.org/10.33976/iugjeps.v28i3.5627

Al-Qudah, M. (2013). "The degree of superstitious thinking among Mutah University students in the Hashemite Kingdom of Jordan and its relationship to some variables", Educational Sciences Studies 40 (3), 865-877. https://journals.ju.edu.jo/DirasatEdu/Article/viewFile/4555/3234

Al-Safi, A. (2001). School climate and its relationship to achievement motivation and level of ambition among a sample of male and female high school students in Abha City, Arabian Gulf Resala Journal, 22(79), 61-9o. Saudi Arabia.

Hammoud, S. (2021). Achievement Motivation and its Relationship to the Control Center of Nursing Students at Tishreen University, Tishreen University Journal for Research and Scientific Studies, Lattakia, Syria.

Jarwan, F. (2016). Teaching thinking, concepts, and applications, 8th edition, Amman: Dar Al-Fikr.

Kadi, M. (2016). The relationship of thinking styles to the achievement motivation among secondary school students, published master's thesis, University of Abi Bakr Belkaid, Algeria.

Kamel, A. (2019). Superstitious thinking and its relationship to the academic self-concept of secondary school students in Baghdad Governorate, Iraqi University Journal, Baghdad. 3(44), 350-365. https://www.iasj. net/iasj/download/d46ec5c56f749bce

Lazem, L. (2020). The degree of prevalence of superstitious ideas among female students of internal departments at the University of Maysan, Maysan Research Journal, Iraq.

Muhammad, J. \& Sharaf, M. (2020). The impact of an educational program on developing achievement motivation among students of the University of Duhok, Dohuk University Journal, Iraq.

Mustafa, M. (2017). Developing thinking skills, dar Al-Bidaa for Publishing and Distribution, Amman: Jordan.

Simamora, B. (2021). How Proponents and Opponents Influence Achievement Motivation: The Role of the Anticipated Emotions of Other People. Gadjah Mada International Journal of Business. 23, (1), 1-35. https://doi.org/10.22146/gamaijb.44042 